\title{
Рецензия на монографию «Exploring the Future of Russia's Economy and Markets: Towards Sustainable Economic Development” (ed. by Bruno S. Sergi. Emerald Publishing Limited, 2019. 288 p.)
}

\author{
И.Д. Тургель
}

Уральский федеральный университет имени первого президента России Б.Н. Ельцина Российская Федерация, 620002, Екатеринбург, ул. Мира, 19

Рецензируемая монография посвящена многостороннему анализу российской экономики и перспективам ее развития в современном мире. В книге дается глубокий анализ финансового и промышленного секторов экономики, промышленной политики, перспектив инновационной и зеленой экономики в России. Обсуждаются вопросы влияния санкций, перспективы развития новых индустрий на базе современных технологий в России.

Ключевые слова: Россия; устойчивое развитие; экономический рост; финансовые технологии; новые технологии; ТНК; инновации; глобальные цепочки добавленной стоимости; сценарии развития

В книге, написанной коллективом ученых при участии и под редакцией профессора Университета Мессины, исследователя Центра российских и евразийских исследований имени Дэвиса Гарвардского университета (Harvard Davis Center for Russian and Eurasian Studies) Бруно Серджи, выполнено многостороннее исследование современного состояния российской экономики и перспектив ее развития в меняющемся современном мире.

Основой для написания книги послужили доклады и обсуждение перспектив мировой и российской экономик на международном семинаре New Reality and Russian Markets, который был организован совместно с Российским университетом дружбы народов и Центром имени Дэвиса и проведен в Гарвардском университете в апреле 2017 г. Среди авторов - ученые из РУДН (С.А. Балашова, А.Э. Березин, Н.А. Волгина, Е.А. Дегтярева, А.М. Зобов, И.В. Лазанюк, В.М. Матюшок, В. Чернова, С.Ю. Черников), МГИМО (Б. Ананьев, Я. Ваславский), Всероссийского научно-исследовательского института экономики сельского хозяйства (А.В. Боговиз, Ю.В. Рагулина), НИУ ВШЭ (М. Кузык, Ю. Симачев), Волгоградского государственного технического университета (Е.Г. Попкова), Российского экономического университета имени Г.В. Пле-

(С) Тургель И.Д., 2019

c) (i) This work is licensed under a Creative Commons Attribution 4.0 International License https://creativecommons.org/licenses/by/4.0/ 
ханова (Е.В. Попова), Университета Нью-Йорка (Кэвин Чен), Университета Алабамы (Шахдад Нагшпур).

Первые главы книги посвящены развитию финансового сектора. В первой главе How Can FinTech Impact Russia’s Development? исследованы вопросы сущности финансовых технологий, задачи, которые они могут решать, и важность их роли в современном мире. В этой главе дается не только обзор и анализ развития финансовых технологий в странах Востока и Запада, но и обозначены направления развития финтеха в России.

Роль коммерческих банков в современной экономике России, состояние и перспективы развития фондового рынка исследованы во второй и третьей главах.

Четвертая глава посвящена развитию индустрий будущего, доказывается, что фокусом современного развития российской экономики должны стать индустрии 4.0. Однако, как показано в пятой главе, современная промышленная политика государства не привела к существенному повышению инновационности российских предприятий. Авторами предлагаются некоторые инструменты промышленной политики, применение которых должно способствовать более активному инновационному развитию.

Вопросам инновационного развития, развития зеленой экономики, снижения потребления ресурсов и загрязнения окружающей среды посвящены отдельные главы книги.

Роль нефтегазового сектора остается неизменно высокой в российской экономике. Перспективам ее развития, в том числе в условиях западных санкций, посвящена одна из глав книги.

Санкции затронули не только российские компании, но и действующие в России иностранные и транснациональные компании. Авторы анализируют санкции как инструмент регулирования международных экономических отношений. Рассматривая российскую экономику как неотъемлемую часть мировой экономики, они показывают, как взаимные ограничительные меры наносят ущерб интересам всех сторон, вовлеченных в процесс.

Методология, основанная на таблицах «затраты - выпуск», использована автором двенадцатой главы для анализа участия России в глобальных цепочках добавленной стоимости (ГЦДС). Показано, что роль России в ГЦДС росла в последние десятилетия преимущественно за счет поставок нефти и газа. Будущие тенденции участия России в глобальных цепочках можно описать двумя сценариями. Первый основан на расширении прямого производственного участия с целью увеличения и диверсификации ненефтяного экспорта. Второй сценарий связан с продолжением участия минеральных ресурсов в ГЦДС, которые Россия реализует до сих пор. Оба сценария имеют свои плюсы и минусы, но автор показывает, что первый сценарий лучшее соотносится с экономическими интересами России и устойчивым развитием.

Вопросам расчета и анализа сценариев развития российской экономики посвящена последняя глава книги. Результаты сценарных расчетов авторов показывают, что реализация целевого сценария экономического роста требует целенаправленных усилий по увеличению человеческого капитала, инвестиций в основной капитал и инновации, диверсификации экспорта и 
достижению совершенства в качестве политических и экономических институтов. Устойчивый рост в 3 \% в год в среднесрочной перспективе возможен только при реструктуризации экономики; в противном случае, даже при благоприятных условиях на товарных рынках и более высокой эффективности существующей экономической системы, невозможно достичь высоких темпов экономического роста, необходимых для существенного улучшения качества жизни.

\title{
Список литературы
}

Exploring the Future of Russia's Economy and Markets: towards sustainable economic development / ed. by Bruno S. Sergi. Emerald Publishing Limited, 2019. 288 p.

\section{История статьи:}

Дата поступления статьи: 26.05.2019

Дата принятия к печати: 15.06.2019

\section{Для цитирования:}

Тургель И.Д. Рецензия на монографию «Exploring the Future of Russia's Economy and Markets: Towards Sustainable Economic Development» (ed. by Bruno S. Sergi. Emerald Publishing Limited, 2019. 288 р.) // Вестник Российского университета дружбы народов. Серия: Экономика. 2019. Т. 27. № 3. С. 604-607. http://dx.doi.org/10.22363/23132329-2019-27-3-604-607

\section{Сведения об авторе:}

Тургель Ирина Дмитриевна, доктор экономических наук, профессор, заместитель директора по науке Высшей школы экономики и менеджмента, Уральский федеральный университет имени первого президента России Б.Н. Ельцина. E-mail: turgel@k96.ru

Review

\section{Book Review of \\ "Exploring the Future of Russia's Economy and Markets: Towards Sustainable Economic Development" (ed. by Bruno S. Sergi. Emerald Publishing Limited, 2019. 288 p.)}

\author{
Irina D. Turgel \\ Ural Federal University named after the First President of Russia B.N. Yeltsin \\ 19 Mira St., Ekaterinburg, 620002, Russian Federation
}

The monograph under review is devoted to a multilateral analysis of the Russian economy and the prospects for its development in the modern world. The book provides an in-depth analysis of the financial and industrial sectors of the economy, industrial policy, and opportunities for an innovative and green economy in Russia. Impacts of sanctions, the prospects for the development of new industries based on modern technologies in Russia are discussed.

Keywords: Russia; sustainable development; economic growth; financial technologies; new technologies; TNCs; innovations; global value chains; development scenarios 


\section{References}

Sergi B.S. (ed.). (2019). Exploring the Future of Russia's Economy and Markets: Towards Sustainable Economic Development. Emerald Publishing Limited.

\section{Article history:}

Received: 26.05 .2019

Accepted: 15.06.2019

\section{For citation:}

Turgel I.D. (2019). Book Review of "Exploring the Future of Russia's Economy and Markets: Towards Sustainable Economic Development" (ed. by Bruno S. Sergi. Emerald Publishing Limited, 2019. 288 p.). RUDN Journal of Economics, 27(3), 604-607. http:// dx.doi.org/10.22363/2313-2329-2019-27-3-604-607

\section{Bio note:}

Irina D. Turgel, Doctor of Economics, Full Professor, Deputy Director for Research, Graduate School of Economics and Management, Ural Federal University named after the First President of Russia B.N. Yeltsin. E-mail: turgel@k96.ru 